\title{
Detection of pathomorphological and immunohistochemical findings of tuberculosis in cattle slaughtered in Ankara and its surroundings
}

\author{
Sevil Atalay VURAL ${ }^{1}$, Mehmet Eray ALCIGIR ${ }^{2}$ \\ ${ }^{1}$ Ankara University, Faculty of Veterinary Medicine, Department of Pathology, Diskapi, Ankara, Turkey; ${ }^{2}$ Ankara University, \\ Graduate School of Health Sciences, Department of Veterinary Pathology, Besevler, Ankara, Turkey.
}

Summary: Macroscopical and microscopical lesions were examined that 4-6 years old, different sex and breeds, 86 of cattle which detected tuberculosis from all materials were collected from slaughterhouses of Ankara and its surroundings. Generally 78 (91\%) were located in the lungs, pleura and regional lymph nodes, $5(6 \%)$ were located in the liver and portal lymph nodes, and 3 (3\%) were generalised. Pathomorphologically, 81 (94\%) comprised miliar-nodular tubercles, and 5 (6\%) were determined to be chronic organ tuberculosis. Ziehl-Neelsen (ZN) stained sections revealed acide fast bacille (AFB) in lung, lymph nodes, liver and trachea (96\%). Immunohistochemically, M. bovis antigens were seen in the macrophages, necrotic areas, and the Langhans giant cells $(96 \%)$ in the same tissues but generally the number and intensity of the positivity were much higher than $\mathrm{ZN}$.

Key words : Cattle, immunoperoxidase, pathology, tuberculosis.

\section{Ankara ve çevresinde bulunan mezbahalarda kesilen sığırlarda saptanan tüberkülozun patomorfolojik ve immunohistokimyasal bulgularının incelenmesi}

Özet: Bu çalışmada Ankara ve çevre il/ilçe mezbahanelerinde kesilen 4-6 yaşlı, farklı ırk ve cinsiyette 86 tüberkülozlu sığırda saptanan makroskobik ve mikroskobik lezyonlar incelendi. Lezyonların 78'inin (\%91) akciğer, plöra ve bölge lenf düğümlerinde, 5'inin (\%6) karaciğer ve portal lenf düğümlerinde bulunduğu, 3'ünün (\%3) ise generalize olduğu görüldü. Bunlardan, 81'i (\%94) milier-nodüler tüberküller ve 5'i (\%6) kronik organ tüberkülozu şeklindeydi. Bu hayvanların \%96'sında akciğer, bölge lenf düğümleri, karaciğer ve traheadan yapılan Ziehl-Neelsen $(\mathrm{ZN})$ boyamada aside dirençli basiller gözlendi. İmmunohistokimyasal olarak da olguların \%96'sında aynı dokularda M. bovis antijenleri makrofajların sitoplazmasında, nekrotik alanlarda serbest halde ve Langhans dev hücrelerinde dikkati çekti. Her iki boyamada aynı oranda etken boyanması saptanmasına rağmen genel olarak immunohistokimyasal boyamalarda etken hem çok daha belirgindi hem de pozitiflik daha yoğundu.

Anahtar sözcükler : İmmunoperoksidaz, patoloji, sığır, tüberküloz.

\section{Introduction}

Tuberculosis (TB) is a zoonotic most important chronic disease with high prevalence among humans, domestic and wild animals in developing countries $(6,8,16,26,29)$. According to the World Health Organization (WHO), $80 \%$ of cases in humans are detected in Third World countries (29). Although TB in humans is primarily caused by Mycobacterium tuberculosis (M. tuberculosis), M. bovis, the cause of TB in cattle, is also responsible for disease in humans usually acquiring the infection as a result of the ingestion of infected uncooked meat, milk and their products $(12,16,22)$. The microorganism is spread in cattle especially by aerosol, but calves can be infected by ingestion of milk or in uterus (16). Therefore, eradicating M. bovis from livestock is of substantial importance to human health and welfare. The microorganism can be transmitted to humans exposed to cattle or other infected animals, and transmission is also possible from human to animals $(6,16)$.

The aim of the study was to examine TB in cattle under slaughterhouse conditions in Ankara and its surroundings, pathomorphologically and immunohistochemically.

\section{Materials and Methods}

Study site and sample population: The visceral organs suspected of TB, pertaining to 86 cattle ( 75 males, 11 females) of 4-6 years of age, different breeds and sex, and which meet the red meat demand of particularly in Ankara and its surroundings, constituted the study material. Although the exact number of animals slaughtered within this period was not able to be accessed, there was examined a total of 5618 animals throughout the study period. 
The postmortem examination was conducted according to the guidelines for the meat inspection (Animal Health Procedure). All major viscera and regional lymph nodes were examined and incised. The location and characteristic of each lesion were recorded. The samples were taken from the lesions together with normal adjacent tissue.

Histopathological and immunohistochemical (IHC) methods: Tissue samples were fixed in $10 \%$ buffered formalin and processed by standard paraffine wax technique. The sections $(5 \mu \mathrm{m})$ were stained with hematoxyline-eosin (HE), Ziehl-Neelsen (ZN) and von Kossa stain.

All paraffin sections were stained with the avidinbiotin complex peroxidase (ABC-P/Universal LSAB 2 Kit, Dako) method by using polyclonal rabbit antiMycobacterium bovis sera (Dako, diluted 1:500). Briefly, after dewaxing and rehydration, endogenous peroxidase activity was blocked with $0.3 \%$ hydrogen peroxide in methanol for $20 \mathrm{~min}$ and treated with pronase for $10 \mathrm{~min}$ at $37^{\circ} \mathrm{C}$ and incubated with normal goat sera for $20 \mathrm{~min}$ at $37^{\circ} \mathrm{C}$. Then the sections were incubated for 1 hour at $37^{\circ} \mathrm{C}$ with polyclonal antibody. Next, the sections were incubated with biotinylated goat anti-rabbit IgG and then with streptavidin-peroxidase reagent for $20 \mathrm{~min}$. Color was developed by a final incubation with 3-amino-9 aethyl carbazole (AEC) for $5 \mathrm{~min}$ at room temperature. Following every step, sections were washed with phosphate buffered saline (PBS), except than the step with normal goat sera. The sections were counterstained with Gill's hematoxyline. Affected ten tissue sections were treated with normal rabbit sera served as controls.

\section{Results}

Macroscopical findings: Amongst the 86 TB cases, $78(91 \%)$ were located in the lungs, pleura and regional lymph nodes, $5(6 \%)$ were located in the liver and portal lymph nodes, and 3 (3\%) were generalised.

Pathomorphologically, 81 cases (94\%) comprised miliar-nodular tubercles, and 5 cases $(6 \%)$ were determined to be chronic organ tuberculosis (Fig. 1). Furthermore, a few hydatic cysts were determined to be scattered in the lungs of 6 cases.

The lesions were localized prominently in caudal lobe $(65 \%)$, caudal-cranial lobe $(13 \%)$, cranial lobe $(3 \%)$, and all lobes (19\%). These were protrusive, hard, whitish yellow nodules ranging from $2-5 \mathrm{~mm}$ to $3 \mathrm{~cm}$ in size that displayed dry and calcified areas in cut sections, and miliar tubercles of similar colour that were either located in the periphery of the above mentioned nodules or were scattered.

In 24 of the indicated cases, nodules of varying size were observed to be either scattered or localized on the parietal, costal pleura.

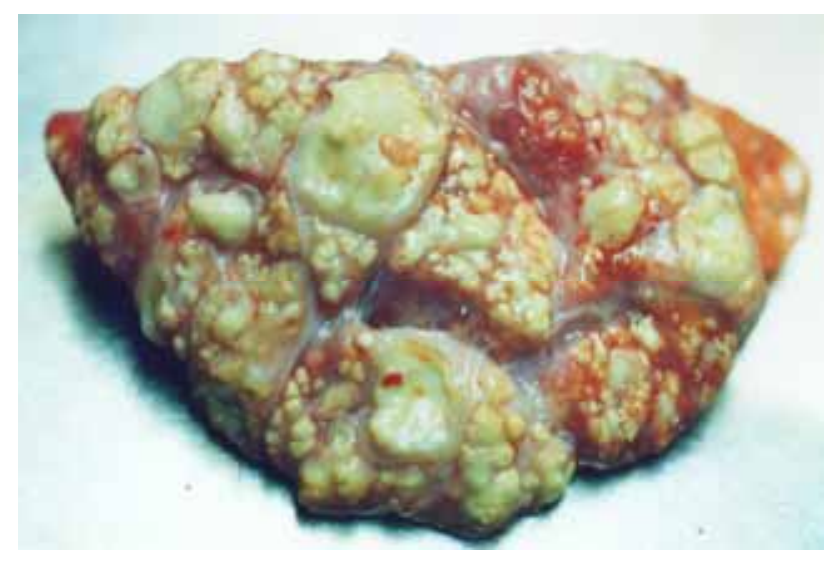

Fig 1. Cut section of chronic organ TB.

Şekil 1. Kronik organ TB'nun kesit yüzü.

Conglomerate tubercles located particularly in the cranioventral lobes and lymph nodes were observed in 17 cases. The upper surface of these structures, that displayed the size of a fist and that had formed upon the mergence of nodules, were irregular. They were protrusive and embedded in the organs. The cut sections, displaying a lobular appearance due to the presence of areas bounded by connective tissue, were partially calcified.

In the five cases $(6 \%)$ diagnosed with chronic organ $\mathrm{TB}$, lesions were determined to be yellowish nodular foci, $1-5 \mathrm{~cm}$ in size and soft and acinous (resembling a cloverleaf) in appearance, located in all lobes and particularly in the caudal lobes. Some displayed calcified areas, similar to plaster and ectatic bronchi and caverns filled with yellowish green purulent exudate were observed in cut sections (Fig. 1). In addition to these findings, tubercles of varying size, either displaying ulcerative surfaces or localized in a narrow area in the form of a chain, were observed to be scattered in the mucosa of the trachea.

Tubercules were determined in the bronchial and mediastinal lymph nodes in all cases. The cut sections of the enlarged lymph nodes were displayed either widespread caseified areas or yellowish white foci, particularly in the cortex.

Five cases were diagnosed as extrapulmonal tuberculosis. In these cases, miliar and nodular tubercles were determined in the liver and portal lymph nodes. Furthermore, in 3 of these cases, similar tubercles were observed in the periton and diaphragma.

The digestive system was not opened due to the hygienic requirements of the abattoirs.

Microscopical findings: A classic granuloma (Fig. 2 ), as a characteristic lesion of TB, composed of a central caseous necrose with mantle of macrophages, lymphocytes, plasma cells, epithelioid macrophages, and Langhans giant cells were seen especially in nodulermiliar TB. The lesions were surrounded by a rim of fibroblasts with interspersed lymphocytes. Often the 
center of the granuloma was necrotic and heavily calcified. Von Kossa stain was revealed granular mineralization of necrotic debris. In chronic visceral TB, tubercles and ulcerative changes were seen in the trachea. But pulmonal lesions were generally involved wide areas of caseification necrosis, neutrophilie leucocytes and mononuclear cells. These lesions were either not limited by a capsule or the capsule was indistinct.

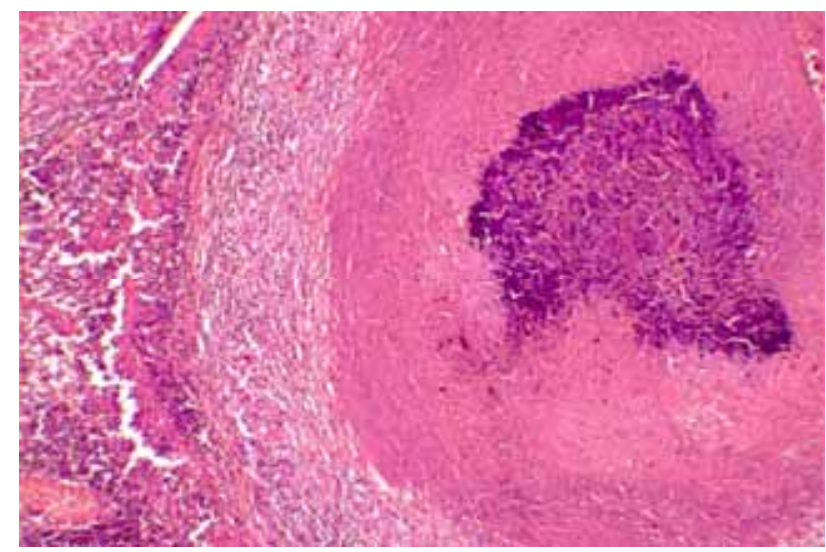

Fig 2. Microscopical appearance of typical tubercle, HE, x100. Şekil 2. Tipik tuberkülün mikroskobik görünümü, HE, x100.

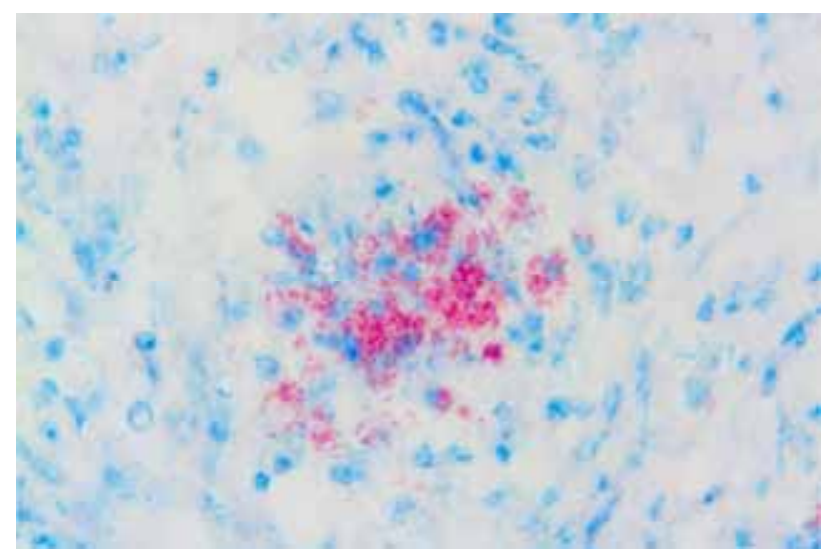

Fig 3. Appearance of AFB in the lung, ZN, $x 400$. Şekil 3. Akciğerde AFB'nin görünümü, ZN, x400.

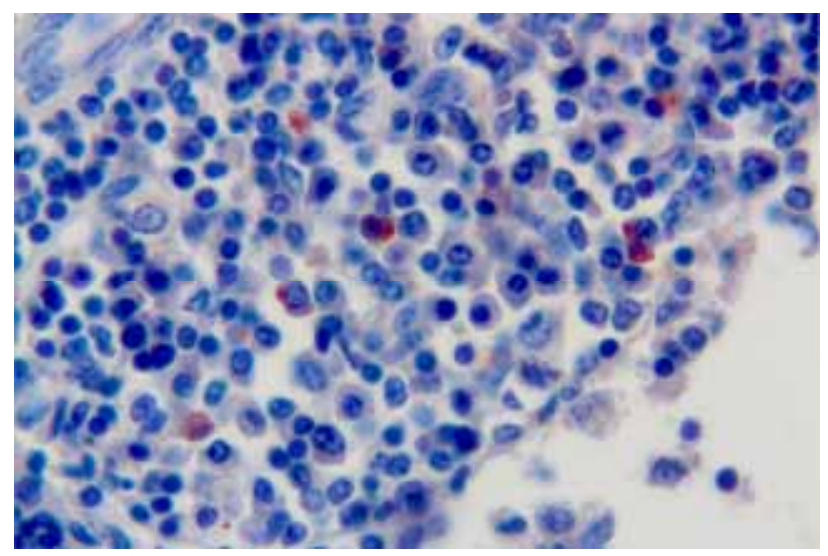

Fig 4. M. bovis antigens in the macrophage, ABC-P, x600. Şekil 4. Makrofajlarda M.bovis antijenleri, ABC-P, x600.
Acide fast bacilles (AFB) which were settled in the macrophages and in the caseous necrotic debris or sometimes in the Langhan giant cells in sections stained $\mathrm{ZN}$, were generally seen in the lung (Fig. 3) and lymph nodes and lesser in the liver and trachea (96\%) either.

Furthermore, pulmonary echinecoccosis (24\%), interstitial pneumonia (52\%) characterized with peribronchial cuffings and thickening of interalveolar areas in the lungs, and pericholangitis (24\%) in the liver were determined.

Immunohistochemical findings : M. bovis (96\%) antigens were mostly seen in the macrophages (Fig. 4), slightly in the caseous necrotic debris and rarely in the Langhan giant cells as reddish colours in the same tissues. But the immunohistochemical stained slides generally showed a much clearer and more striking positivity than $\mathrm{ZN}$ method.

\section{Discussion and Conclusion}

The prevalence of TB at slaughter is reported to be significantly greater in dairy cattle than in beef cattle $(1,7,24)$. The threat to human health by dairy cattle with TB is substantial because of consuming unpasteurized milk and its product $(12,16,22)$. In the same time, the disease when it involves the genital tract impairs the breeding efficiency of the animals and negatively affects the dairy economics (24). When TB involves the uterus, abortion may occur. In advanced cases, early embryonic death or even failure in implantation and sterility may result. In addition, the affected animal acts as a source of infection to the opposite sex $(2,9)$ but genital TB was not found in this study. And the study material belonged either to small-scale operators or to individual dairies. The incidence of the disease in stock holdings for meat cattle was very low.

The diagnosis of TB in cattle can be made when typical tubercles are detected in carcasses at slaughterhouses. Inspection of these organs during slaughter may provide a more rapid and reliable diagnosis of TB than bacteriologic culture, depending on the experience of the person and careful examination. Other laboratory techniques like $\mathrm{HE}, \mathrm{ZN}$, and ABC-P stains were exact diagnosed Mycobacterium sp. positivity.

The findings were generally seen similar to different studies $(6,15,16,25,26)$. In the cases the presence of exuberant pus in both the cut sections and bronchi with chronic organ TB, and microscopically, the presence of wide areas of caseification and neutrophile leucocytes, and the indistinction of boundaries were evident. Tubercles in certain areas of the lungs and regional lymph nodes were concluded to have developed upon previous infection. For hyper and/or super 
infections are involved in the development of this type of TB.

M. bovis infections can occur congenitally $(3,6)$ but commonly have a greater distribution lungs, thoracic lymph nodes and pleura in cattle $(4,6,10,16,23,24,32)$ and the predilection sides have been interpreted as evidence of respiratory route of infection $(6,16,26)$ while predilection for abdominal viscera especially liver and its lymph nodes have been interpreted as evidence of oral exposure $(18,19)$. The lung lesions were reported in 7 $17 \%(7,17,31)$ in cattle examined at an abattoir. However, careful examination of the lungs has revealed lung lesions in as many as $73-89 \%$ of cattle $(4,10,21,23,28)$. Some searchers reported a $90-98 \%$ agreement between diagnosis of TB based on histopathology $(11,30)$ and generalized infection was in $19.1 \%$ (26). When considering animals with lesions in the organs of body cavity, the thorax in the study was affected in $91 \%$ and the abdomen in $6 \%$ compared with $55-60.5 \%$ and $2.1-5 \%$ quated in different studies $(13,30,32)$. Also in the study, the tubercles were seen both abdomen and thorax in $3 \%$. The predilection site has been reported in the caudal lobes $(20,21,25,28)$. The lesions, despite being spread within all lobes (19\%), were particularly prominent in the caudal lobes $(65 \%)$ in the study. The lymph node lesions also predominated in the study, and most of them were caseous and mineralized in character. In the study, 78 (91\%) of cattle with lesions had thoracic involvement incluiding lung, pleura and regional lymph node lesions, suggests that aerosol transmission was most important in the spread of the disease. Approximately $24 \%$ of the cattle were seen only hydatid cysts in lungs in the study. One of them was determined in chronic organ $\mathrm{TB}$, and re-infection and hyperinfection were concluded to cause predisposition to the development of the TB. Microscopic examination also demonstrated the presence of areas of interstitial pneumonia (52\%), considered to be related to hyperergia. In the study, the lesion distribution identified but did not correlate well with the more detailed some studies in which the mesenteric lymph nodes, spleen, kidney, genital system, digestive system, tonsil, cerebrum, and cerebellum did not determined as the enormous diseased vital organs $(5,6,16,26)$. Digestive system was not evaluated because of the hygienic requirements of the abattoirs. Even, the mesenterial lymph nodes were recorded the most common site of involvement (34.5\%) (26). There was determined hydatid cyst and giant liver flukes (Fasciolides manga) hydatid cyst in some studies $(14,32)$. Pericholangitis was seen in the study and their cause was not determined.

Acide fast bacille were observed only in giant cells and in nectoric areas by researcher $(15,27)$ and any differences were reported in the number of positive animals by the two methods except than organism dense. In this study, immunohistochemically the antigens were determined generally cytoplasma and/or outside of macrophages, rarely in Langhans giant cells in $96 \%$ of the cases. On he other hand, in remaining $\mathrm{ZN}$ positive $4 \%$ of cases IHC negative result obtained. To out opinion, these cases were considered either to originate from different type Mycobacterium infection or antigen denaturation. But generally the number and intensity of the positivity were much higher in the ABC-P than $\mathrm{ZN}$ stained some slides and the organism was not seen observed in neutrophile leucocytes by the two methods opposed to the researchers. The density of AFB observed in the cases of chronic organ $\mathrm{TB}$, was very low in both stainings.

In conclusion, bovine $\mathrm{TB}$ is a substantial economic importance to cattle farming and still poses a threat to animal health in our countries and further researches to provide an understanding, protection, eradication, and control. TB control policies have relied on the testing of cattle herds and the slaughter of infected the animals. This approach has been effective in eradicating the diseases. Because infected free-living animals were seen as a possible source of contamination.

This study is considered to bear significance with respect to the underlying of the presence of the infection despite numerous protective and/or control measures developed at present, and the risk posed by products originating from infected animals to the public of countries in which the infection exists. The study provides an indication of the lesion distribution in cattle.

\section{Acknowledgement}

We thank to Dr. Hikmet Keles and Dr. Mehmet Fatih Bozkurt for design of figures.

\section{References}

1. Anda JH, Evangelista R, Valencia GL, Hodgers MM (1997): An abattoir monitoring system for diagnosis of tuberculosis in cattle in Baja California, Mexico. J Am Vet Med Assoc, 211, 709-711.

2. Anonymous (1991): TB and deer farming: Return of the king's evil? Lancet, 338, 1243-1244.

3. Atalay Vural S, Tunca R (2001): Generalized tuberculosis in a 45 day-old calf. Deutsc Tierrär Wochen, 108, 468-470.

4. Beytut E (2001): Pathological examinations on the localization of lesions and incidence of tuberculosis in cattle in Kars city and its surrounding. Vet J Kafkas Uni, 7, 15-25.

5. Cassidy JP, Bryson SD, Neill SD (1999): Tonsillar lesions in cattle naturally infected with Mycobacterium bovis. Vet Rec, 144, 139-142.

6. Caswell JL, Williams KJ (2008): Respiratory system. Tuberculosis. 606-610. In: Maxie, MG (Ed), Jubb, Kennedy and Palmer's Pathology of Domestic Animals, $5^{\text {th }}$ ed. Elsevier, China. 
7. Corner LA, Melville L, McCubbin K (1990): Efficiency of inspection procedures for the detection of tuberculosis lesions in cattle. Aust Vet J, 67, 389-392.

8. Delahay RJ, Leeuw ANS, Barlow AM, Clifton-Hadley RS, Cheeseman CL (2002): The status of Mycobacterium bovis infection in UK wild mammal: A review. Vet J, 164, 90-105.

9. Deshpande BR, Sardeshpande PD, Sane CR (1966): Tuberculous endometritis in a buffalo cows. Indian Vet J, 43, 288-291.

10. Diker F (1989): Bursa yöresinde cesitli trk sigirlarda gorulen tuberkuloz lezyonlarinin organlara dagilısi ve histolojik yapilari. Pendik Hayv Hast Merk Araş Enst Derg, 20, 78-94.

11. Duffield BJ, Norton JH, Streeten TA (1985): Application of the comparative cervical test to the identification of false positive reactions to the bovine tuberculin caudal fold test. Aust Vet J, 62, 424-426.

12. Essey MA, Koller MA (1994): Status of bovine tuberculosis in North America. Vet Microbiol, 40, 15-22.

13. Francis J (1958): Tuberculosis in Animals and Man. A Study in Comparative Pathology. Cassell and Company, London.

14. Guilbrid PDL, Rollinson DHL, McAnulty EG, Alley JG, Wells EA (1963): Tuberculosis in the free living African (Cape) buffalo (Syncerus CafferCaffer Sparrman). J Comp Path, 73, 337-358.

15. Gutierrez Cancela MM, Garcia Marin JF (1993): Comparison of Ziehl-Neelsen staining and immunohistochemistry for the detection of Mycobacterim bovis in bovine and caprine tuberculous lesions. J Comp Path, 109, 361-370.

16. Jones TC, Hunt RD, King NW (1994): Diseases caused by bacteria. 413-504. In: Jones TC, Hunt RD, King NW (Eds), Veterinary Pathology, $6^{\text {th }}$ ed. Williams and Wilkins, Baltimore.

17. Lepper WD, Pearson CW (1973): The route of infection in tuberculosis in beef cattle. Aust Vet J, 49, 266-267.

18. Lesslie IW, Birn KJ (1967): Tuberculosis in cattle caused by the avian type tubercle bacillus. Vet Rec, 80, 559-564.

19. Lugton IW, Wobeser G, Morris RS, Caley P (1997): Epidemiology of Mycobacterium bovis infection in feral ferrets (Mustela furo) in New Zealand: I.Pathology and diagnosis. New Zealand Vet J, 45, 140-150.

20. McKay WM (1959): A clinical study of bovine tuberculosis in Banffshire. The pathological lesions, part 2. British Vet J, 115, 370-377.

21. McIlroy SG, Neill SD, McCracken RM (1986): Pulmonary lesion and Mycobacterium bovis excretion from the respiratory tract of tuberculin reacting cattle. Vet Rec, 118, 718-721.
22. Murray PR (1993): Bacteriology. 1-27. In: Murray PR, Drew WL, Kobarashi GS, Thompson IH (Eds), Medical Microbiology. Wolfe Publishing, London.

23. Ortatatli M, Ciftci MK, Tuzcu M (1998): Siğırlarda tüberküloz ve diğer granulomatöz pnömoniler üzerinde patolojik incelemeler. Selçuk Univ J Vet Sci, 14, 139-150.

24. Ozmen O, Kurşun O, Ozcelik M (2005): Bovine tuberculosis in Burdur, southern Turkey: Epidemiological, pathological and economic study. Int J Tuberc Lung Dis, 9,1398-1402.

25. Palmer MV, Waters WR, Whipple DL (2002): Lesion development in white-tailed deer (Odocoileu virginianus) experimentally infected with Mycobacterium bovis. Vet Pathol, 39, 334-340.

26. Ragg JR, Waldrup KA, Moller H (1995): The distribution of gross lesions of tuberculosis caused by Mycobacterium bovis in feral ferrets (Mustela furo) from Otago, New Zealand. New Zealand Vet J, 43, 338-341.

27. Roels S, Walravens K, Saegerman C, Thelissen M, Vanopdenbosch E, Godfroid J (2003): Mycobacterium bovis meningitis in a cow with clinical signs of BSE. Vet Rec, 152, 807-808.

28. Stampt JT (1944): A review of the pathogenesis and pathology of bovine tuberculosis with special reference to practical problems. Vet Rec, 56, 443-446.

29. Styblo K, Rouillon A (1981): Tuberculosis in the world estimated global incidence of smear positive pulmonary tuberculosis. Unreliability of officially reported figures on tuberculosis. Bull Int Uni Tuberc, 56, 118-126.

30. Tammemagi L, Simmons GC, Kelman R, Hall WT (1973): A study of tuberculosis-like lesions in cattle slaughtred in Queensland meatworks. Aust Vet J, 49, 507 511.

31. Whipple DL, Bolin CA, Miller JM (1996): Distribution of lesions in cattle infected with Mycobacterium bovis. J Vet Diagn Invest, 8, 351-354.

32. Whiting TL, Tessaro SV (1994): An abattoir study of tuberculosis in a herd of farmed elk. Canadian Vet J, 35, 497-501.

Geliş tarihi: 05.03.2009 / Kabul tarihi: 23.12.2009
Adress for correspondence
Sevil Atalay Vural, Prof. Dr.
Department of Pathology,
Faculty of Veterinary Medicine, Ankara University, 06110, Diskapi, Ankara, Turkey
E-mail:sevilvural@yahoo.com, svural@veterinary.ankara.edu.tr Tel: $+90312-3170315 / 276$
Fax: $+90312-3164472$ 